\title{
Some Factors Affecting Semen Characteristics, Mating and Lambing Performance of Rahmany Rams
}

A. M. Aboul-Naga, G. Ashmawy and S. El-Nakhla

Animal Production Research Institute, Ministry of Agriculture, and Faculty of Agriculture, Cairo University, Egypt.

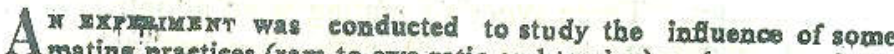
A matizg practices (ram-to-ewe ratio and teasing) and season of mating (autumn vs. spring) on mating and lambing performances of Rahmani sheep. Semen characteristics of the rams were also investigated. Eight rams and 210 ewes were available in each mating season.
\end{abstract}

Different semen characteristics :ejaculate volume, sperm concentration $/ \mathrm{ml}$, directional motility, $\%$ of dead sperm cells and abnormal sperm cells were significantly better in the spring than in the autumn season.

Decreasing ram-to-ewe ratio from $1: 30$ to $1: 20$ had non-signifcant effect on different mating performance parameters. The presence of a teaser ram increased, non-significantly, $\%$ of ewes served during the first oestrous cycle and over the five weeks of joining, but increased $\%$ of ewes reserved.

The wider ram -to-ewe ratio $(1: 30)$ significantly $(\mathrm{P}<.05)$ decreased lambs born/ewe lambing. Other lambing parameters were not significantly affected by mating type.

Autumn mating resulted in a highly significant increase in $\%$ of ewes served in both oestrous cycles. More than $81 \%$ of ewes were served during the first three weeks of joining in the autumn vs. $72.9 \%$ in the spring. Some lambing parameters (ewes conceived/ewe joined, ewes conceived per ewe joined and present at lambing/ewe served ) did not show significant seasonal variations. Other parameters (lambs born/ewe lambed and ewes gave multiple births /ewe lambed ) were significantly higher in the autumn.

Mating management constitutes the most important single aspect determining the success of reproduction (Von Tonder, 1972).

The results reported in this paper were undertaken with the intention of obtaining information upon the influences of some mating practices i.e. ram-to ewe ratio and teasing, on mating and lambing performance of local Rahmani rams. Semen characteristics of the rams were also investigated. 


\section{Material and Methods}

The present experiment was carried out at El-Serw Experimental Farm, Animal Production Research Institute, located in North Delta. Eight Rahmani rams, 2-3 years old and 210 Rahmani ewes, 2-6 years old, were derived from the flock in two successive mating seasons, the autumn (September 1975), and the spring (May 1976). One week prior to the mating time, two ejaculates were collected from each ram using artificial vagina, volume of each ejaculate was recorded to the nearest $0.1 \mathrm{ml}$.Directional motility, number of sperm cells $/ \mathrm{ml}$ number of abnormal sperm cells, $\%$ of dead sperm cells were estimated in a combined sample of the two ejaculates.

In each season, the ewes were randomly allotted to eight groups, each group was given at random one of the eight rams previously tested for semen characteristics. Three types of mating were adopted, one $\mathrm{ram} / 30$ ewes (three group), one ram + teaser $/ 30$ ewes, (two groups), one $\mathrm{ram} / 20$ ewes (three groups). Each group was continuously kept in a $7 \times 10$ meter pen for 35 days (nearly two oestrous cycles) after which the rams were separated from the ewes. Mating performance of each group was studied by estimating number of ewes served/ewe joined in each oesturos cycle, number of ewes reserved/ewe joined and number of ewes served weekly. At lambing time the following parameters were estimated for each mating group or type: ewes conceived/ ewe joined,ewes conceived/ewe present at lambing, ewes lambed/ ewe served, lambs born/ewe lambed and ewes gave multiple birth/ewe lambed. The flock grazed on Egyptian clover (Trifolium alexan-drium) from December till May. During summer and autumn months the animals either grazed crop residuals or were pen-fed on clover hay plus supplements of concentrate mixture $(13 \%$ digestible protein and $50 \%$ starch value). An allowance of '1/4 $\mathrm{kg}$ of concentrates was given to each ewe one week before and two weeks during each mating season. An extra amount of $1 / 3 \mathrm{~kg}$ of the concentrate mixture was also provided to each ram two weeks before and throughout the mating season.

Metrological information used were obtained from a neighbouring metrological station.

The data were subjected to analysis of variance (Snedecor and Cochran, 1970) and t-test was carried out to test the significancy of the differences between the mating types.

\section{Results and Discussion}

\section{A. Semen characteristics}

Semen qualities of the studied rams (Table 1) fall within the range reported other workers for local rams (Hafez et al., 1954, EI-Shahidi, 1973; El-Gamal, 1975; and Mohamed, 1978). According to the known indices, semen collected in the two seasons is judged to be of good quality.

Egypt. J. Anim. Prod. 20, No. 1 (1980) 
Ejaculate volume, sperm cell concentration/ml, directional motility, $\%$ abnormal sperm cells, $\%$ ofdead sperm cells were better in the spring than in the autumn (Table 1). Seasonal differences were statistically significant $(P<0.01)$ for all seminal charactereistics studied (Table 2). Seasonal variations in semen qualities of the ram in the sub-tropical region were observed and reported by many authors (Juma and Dessouky, 1969; EI-Gamal, 1975 and Mohamed, 1978).

TABLE 1.Physical semen characteristics of Rahmani rams.

\begin{tabular}{|c|c|c|c|c|c|}
\hline Seasons & $\begin{array}{c}\begin{array}{c}\text { Volume } \\
\text { ml }\end{array} \\
\times \pm \text { S.E. }\end{array}$ & $\begin{array}{c}\text { Sperm cell } \\
\text { concentration } \\
\left(\mathrm{X} 10^{6} \mathrm{mil}\right) \\
\times \pm \text { S.E. }\end{array}$ & $\begin{array}{c}\text { Directional } \\
\text { motility } \\
(\%) \\
\times \pm \text { S.E. }\end{array}$ & $\begin{array}{c}\text { Abnormal } \\
\text { sperm } \\
(\%) \\
\times \pm \text { S.E. }\end{array}$ & $\begin{array}{l}\text { Dead } \\
\text { sperms } \\
\times \pm \text { S.E. }\end{array}$ \\
\hline Autumn & $0.70 \pm 0.05$ & $3.48 \pm 0.08$ & $69.5 \pm 3.3$ & $8.4 \pm 0.8$ & $31.1 \pm 3.4$ \\
\hline Spring & $1.14 \pm 0.11$ & $3.80 \pm 0.2$ & $80.8 \pm 2.6$ & $5.6 \pm 0.6$ & $20.8 \pm 2.2$ \\
\hline Overall mean & $0.92 \pm 0.10$ & $3.65 \pm 0.05$ & $75.1 \pm 3.0$ & $7.0 \pm 0.7$ & $25.9 \pm 2.8$ \\
\hline
\end{tabular}

TABLE 2. Analysis of variance for semen characteristics.

\begin{tabular}{|c|c|c|c|c|c|c|c|c|c|c|c|}
\hline \multirow{2}{*}{$\begin{array}{l}\text { Source of } \\
\text { variation }\end{array}$} & \multirow{2}{*}{ d.f. } & \multicolumn{2}{|c|}{$\begin{array}{c}\text { Ejaculate } \\
\text { volume } \\
\text { (mi) }\end{array}$} & \multicolumn{2}{|c|}{$\begin{array}{c}\text { Sperm cell } \\
\text { concentration } \\
\left(\mathrm{X} 10^{6} / \mathrm{ml}\right)\end{array}$} & \multicolumn{2}{|c|}{$\begin{array}{c}\text { Advanced } \\
\text { motility } \\
\%\end{array}$} & \multicolumn{2}{|c|}{$\begin{array}{c}\text { Abnormal } \\
\text { sperm cells } \\
\%\end{array}$} & \multicolumn{2}{|c|}{$\begin{array}{c}\text { Dead sperm } \\
\text { cells } \\
\%\end{array}$} \\
\hline & & M.S & $\mathrm{CV} \%$ & M.S. & $\mathrm{CV} \%$ & M.S. & $\mathrm{CV} \%$ & M.S. & $\mathrm{CV} \%$ & M.S. & $\mathrm{VC} \%$ \\
\hline $\begin{array}{l}\text { Between } \\
\text { seasons }\end{array}$ & 1 & $0.77 *$ & 46.9 & $393.8 *$ & 46.2 & $232.1 *$ & 42.9 & $39.8 *$ & 47.4 & $138.8^{*}$ & 32.6 \\
\hline $\begin{array}{l}\text { Between } \\
\text { animals } \\
\text { within } \\
\text { seasons }\end{array}$ & 14 & 0.09 & 53.9 & 49.9 & 53.8 & 33.1 & 57.1 & 4.9 & 52.6 & 28.6 & 67.4 \\
\hline $\begin{array}{c}+ \text { Mean } \\
* \mathrm{P}<\end{array}$ & $\begin{array}{l}\text { quar } \\
.05\end{array}$ & & $\begin{array}{l}+\mathrm{Va} \\
* * \mathrm{P}<\end{array}$ & $\begin{array}{l}\text { iance } \mathrm{c} \\
0.01\end{array}$ & ipone & $t$ perc & & & & & \\
\hline
\end{tabular}

Ambient temperature and day length during spermatogenesis had been reported to be the main climatic factors causing seasonal variations in semen quality (Hafez et al., 1954 and Cupps et al., 1960). They believed that high temperature affects spermatogenesis via sperm migration and pituitary functions. The adverse effect of long photo-period was discussed by Ortavant (1956)

Egypt. J. Anim. Prod. 20, No. 1 (1980) 
and Fowler (1962). They showed that increasing day length induced degeneration of testicular germ cell. Ambient temperature was 21 and $32^{\circ}$ in April and August respectively, i.e. one month before semen collection in the spring and the autumn respectively. Day length averaged 12.0 and $13.9 \mathrm{hr}$ during March and July, respectively. The results reported here is supported by the findings of Mohamed (1978) who found that periods of ingest day length were related to the best semen quality of Ossimi and Rahmani rams and vice-versa.

Better semen characteristics in the spring season than in the autumn could be attributed to better nutritonal conditions during the earlier season. Improved nutrition was reponted by Mattner and Braden (1975) to promote semen quality of raxas. Individual variationsa mong rams in semen characteristics proved to be high and contributed the highest to the variation in different semen characteristics studied (Table 2). Hafez et al. (1954) and El-Gammal (1975) reported also high individual variations in different semen charcteristics of indigenous rams.

\section{B. Mating performance}

The presence of a teaser ram increased $\%$ of ewes served in the first oestrous cycle and allover the 35 days of joining. However, higher $\%$ of ewes were reserved in teased groups in both seasons (Table 3). It secms that the competition between the teaser and fertile ram on ewes in oestrous did not allow the fertile ram to copulate the ewe in a proper way. However, differences due to teasing failed to attain statistical significancy (Table 4). Similar observations were given by Schinckel (1954). Effect of ram to ewe rats was found to differ from one season to another. Decreasing this ratio from $1: 30$ to $1: 20$ improved the mating performance parameters in the autumn, but reverse was the case in the spring. However, the differences were light and statistically non-significant.

Percent of ewes served in the first oestrous cycle was higher in the autumn than in the spring and consequently $\%$ of ewes served in the second oestruous cycle was less (Table 3). Seasonal differences in both parameters were statistically highly significant where it was intangblie and non-significant for other mating performance parameters (Table 4).

For different types of mating, $\%$ of ewes served in the autumn reached its peak in the first week of joining. After the second and the third week of joining 65.7 and $81 ; 9 \%$ of the ewes were served, respectively (Fig. 1). In the spring, $\%$ of ewes served was at its maximum in the third week of joining. After two three weeks of joining only 40.5 and $72.9 \%$ respectively of the ewes were served respectively. Oestrus occurrence in local ewes was reported to be more intense in the autumn than in the spring (Mounib et al., 1956; Aboul-Naga, 1977 and Mohamed, 1978). It may be suggested that of autumn mating season is adopted to obtain three lambing crops per two years, the ram could be left with ewes for only three weeks. Interaction between type of mating $\mathrm{x}$ season was highly significant for ewes served in the 35 days of joining (Table 4).

Egypt. J. Anim. Prod. 20, No. 1 (1980) 
TABLE 3. The effect of ram-to-ewe ratio and teaser ram on the mating performance

\begin{tabular}{|c|c|c|c|c|c|}
\hline \multirow[t]{4}{*}{ Aututm } & $1: 30$ & 75.6 & 11.5 & 10.0 & 88.2 \\
\hline & $1: 30+$ treaser & 84.7 & 10.3 & 15.0 & 94.9 \\
\hline & $1: 30$ & 89.9 & 8,4 & 50 & रु. 3 \\
\hline & Average & 83.4 & 10.1 & 10.0 & 938 \\
\hline \multirow[t]{4}{*}{ Spring } & $1: 30$ & 62.2 & 34.5 & 11.1 & 96.6 \\
\hline & $1: 20+$ treaser & 68.4 & 31.7 & 16.7 & 100.0 \\
\hline & $1: 20$ & 60.0 & 25.0 & 6.7 & 85.0 \\
\hline & Average & 63.5 & 30.4 & 11.5 & 93.9 \\
\hline
\end{tabular}

TABLE 4. Analysis of variance for mating performance traits.

\begin{tabular}{|c|c|c|c|c|c|}
\hline $\begin{array}{l}\text { Source of } \\
\text { variation }\end{array}$ & d.f. & $\begin{array}{l}\text { No.of ewes } \\
\text { served in Ist } \\
\text { oestrous } \\
\text { cycle }\end{array}$ & $\begin{array}{l}\text { No.of ewes } \\
\text { served in } 2 \text { nd } \\
\text { oestrous } \\
\text { cycle }\end{array}$ & $\begin{array}{l}\text { No.of ewes } \\
\text { reserved }\end{array}$ & $\begin{array}{c}\text { No. of ewes } \\
\text { served in } \\
35 \text { days }\end{array}$ \\
\hline $\begin{array}{l}\text { Type of } \\
\text { mating (M) } \\
\text { Season (S) } \\
\text { MXS Interaction } \\
\text { Error }\end{array}$ & $\begin{array}{l}2 \\
1 \\
2 \\
10\end{array}$ & $\begin{array}{l}50.2 \\
76.38 \\
64.1 \\
20.6\end{array}$ & $\begin{array}{r}32.5 \\
915.1 \\
3.0 \\
23.54\end{array}$ & $\begin{array}{r}151.0 \\
1.2 \\
3.0 \\
38.6\end{array}$ & $\begin{array}{c}84.5 \\
1.8 \\
432.2^{* *} \\
28.2\end{array}$ \\
\hline
\end{tabular}

\section{Lambing performance}

The presence of a teaser ram in the mating pen improved different lambing parameters in the spring (Table 5). While in the autumn only fertility parameters, i.e ewes conceived by ewe/joined or present at lambed and ewe lambed/ewe served, were promoted by using a teaser ram. The decrease in number of ewes assigned to the ram from 30 to 20 ewe improved most of the lambing perfommance traits considered, especially number of lambs born/ewe lambed.

Type of mating, however, had a non-significant effect on all parametes exce $t$ lambs born/ ewe lambed (Table 6). The t-test showed a non-significant difference between teased and unteased groups and a significant $(p<005)$ difference between the two ram-to-ewe ratios. The smaller 1 am-to-ewe ratio had been reported by Prud-Hon et al. (1976) to give highor rate of fertility than the wider ratio.

Egypt. J. Anim. Prod. 20, No, 1 (1980) 
TABLE 5. The influence of ram-to-ewe ratio and teasing on lambing performance.

\begin{tabular}{|c|c|c|c|c|c|c|}
\hline \multirow[b]{2}{*}{ Season } & \multirow[b]{2}{*}{$\begin{array}{l}\text { Type of } \\
\text { mating }\end{array}$} & \multirow[b]{2}{*}{$\begin{array}{l}\text { Ewe conc- } \\
\text { eived /ewe } \\
\text { joined }\end{array}$} & \multicolumn{2}{|c|}{ Parameter } & \multirow{2}{*}{$\begin{array}{l}\text { Lambs } \\
\text { born/ ewe } \\
\text { lambing }\end{array}$} & \multirow[b]{2}{*}{$\begin{array}{l}\text { Ewes } \\
\text { giving } \\
\text { multiple } \\
\text { births }\end{array}$} \\
\hline & & & $\begin{array}{l}\text { Ewe conc- } \\
\text { eived /ewe } \\
\text { Present at } \\
\text { lambing }\end{array}$ & $\begin{array}{c}\text { Ewe } \\
\text { lambed/ } \\
\text { ewe served }\end{array}$ & & \\
\hline \multirow[t]{4}{*}{ Autumn } & $1: 30$ & 0.689 & 0.732 & 0.829 & 1.51 & 0.482 \\
\hline & $1: 30+$ teaser & 0.783 & 08.11 & 0.839 & 1.48 & 0.479 \\
\hline & $1: 20$ & 0.783 & 0.798 & 0.83 & 1.161 & 0.591 \\
\hline & Average & 0.752 & 0.780 & 0.827 & 1.56 & 0.517 \\
\hline \multirow[t]{4}{*}{ Spring } & $1: 30$ & 0.778 & 0.778 & 0.804 & 1.20 & 0.208 \\
\hline & $1: 30 \div$ teaser & 088.3 & 0.883 & 0.883 & 1.26 & 0.247 \\
\hline & $1: 20$ & 08766 & 0.781 & 0.906 & 1.39 & 0.390 \\
\hline & Average & 0.809 & 0.814 & 0.864 & 1.28 & 0.282 \\
\hline
\end{tabular}

TABLE 6. Analysis of variance for lambing performance.

\begin{tabular}{|c|c|c|c|c|c|c|}
\hline & & & Mean : & Iares & & \\
\hline $\begin{array}{l}\text { Source of } \\
\text { variation }\end{array}$ & d.f. & $\begin{array}{l}\text { conceived/ } \\
\text { ewes } \\
\text { joined }\end{array}$ & $\begin{array}{l}\text { Ewes/con- } \\
\text { cieved/ewes } \\
\text { present at } \\
\text { lambing }\end{array}$ & $\begin{array}{c}\text { Ewes } \\
\text { lambed/ } \\
\text { ewes } \\
\text { served }\end{array}$ & $\begin{array}{c}\text { bornd/ } \\
\text { ewes } \\
\text { lambing }\end{array}$ & $\begin{array}{l}\text { giving } \\
\text { multiple } \\
\text { births }\end{array}$ \\
\hline Type of mating (M) & 2 & 63.66 & 56.05 & 37.95 & $0428^{*}$ & 143.01 \\
\hline Season (S) & 1 & 56.17 & 16.91 & 71.24 & 1. $32 * *$ & $833.48 * *$ \\
\hline MXS Interaction & 2 & 30.66 & 17.56 & 75.09 & 0.05 & 12.48 \\
\hline Error & 10 & 22.87 & 35.39 & 74.36 & 0.5 & 44. \\
\hline
\end{tabular}

Egypt. J. Anim. Prod. 20, No. 1 (1980) 
The fertility traits were found to be non-significantly better in the spring than in the autumn. This can be attributed to the better semen characteristics of the rams in the spring and to the high number of services performed by these rams in the spring mating as had been recorded by Ashmawy et al. (1979). On the other hand, parameters concerning prolificacy were significantly $(\mathrm{P}<0.01)$ higher in the autumn than in the spring season. The shorter day length during the autumn may likely increased ovulation rate in the local ewes. Aboul-Naga (Unpublished) recorded similar findings on the local ewes bred three times each two years.

Finally it is worthy mentioned that, the work reported here focused attention on two sources of the reproductive failure in the local sheep. The first occrured at mating time as the proportion of ewes conceived/ewe joined ranged from 0.689 to 0.883 , which means a reproductive wastage of 0.117 to 0.311 perewe joined. The second took place along the course of pregnancy as eweslambed served ranged from 0.804 to 0.906 . Thus the proportion of ewes served and per ewe failed to give birth was 0.094 to 0.196 . It should be stated that the mating practices used in this study did not succeed in reducing any of these two sources of reproductive wastage. It may be suggested to carry out further research work on this area of study.

\section{References}

Aboul-Naga, A.M (1978) Using Suffolk sheep for improving lamb production from subtropcial Egyptian sheep. 1. Reproductive performance. J. Agric. Sci. Camb., 90, 125.

Ashmawy, G. Aboul-Naga, A.M. and El-Nakhla S. 1979 Libido and mating behaviour in rams. Rahmani Egypt. J. Anim. Prod., (in presss).

Allison, A.J. (1978). Flock mating in sheep. II. Effect of number of ewes per ram on mating behaviour and fertility of two-tooth and mixed age/Romney ewes run together, New Zealand .J. Agric. Res. 20, 120. (A.B.A. 46, 1337.)

Cupps, P.T.M., McGowan B. D.F. Reddon A.R. and Weir W.C. (1960). Seasonal changes in the semen of rams. J. Anim. Sci. 19, 208.

El-Chahidi, A.A. (1973) Evaluation and preservation of ram season semen. M.Sc. Thesis, Fac. Vet., Cairo University, Egypt.

El-Gamal/, A.A. (1975) Genetic studies on sexual behaviour of rams.M. Sc. Thesis, Fac. Agric, Ain-Shams Univ. Cairo Egypt.

Fowler, D.G. (1962) The effect of light on the semen characteristics of the Merino ram. In. Artificial breeding of sheep in Australia pp. 113-117 (-A.B.A, 31 1277).

Hafez, E.S.E., Badreldin, A.L. and Darwish, Y.H. (1954) Seasonal variations in semen characteristics of sheep in the subtropics. JAgric. Sci. 45, 28. Juma, K.H. and Dessouky, F. (1969) Semen characteristics of Awassi rams.J. Agric. Sci,
Camb. 73, 311 .

Lightfoot, R.J., Simth, J.A.C. (1968) Studies on the number of ewes joined per ram for flock matinges under paddock conditions. I. Mating behaviour and fertility. Aust. J. Agric 19, 1029.

Mattner, P.E. and Braden, A.W.H. (1975) Studies of flock mating of sheep 1.Influence of Agric. age hormone treatment, shearing and diet on the libido of Merino rams., Aust. $J$. Exp. Anim. Husb., 15, 300.

Mohamed, S.A. (1978) Studies on some reproductive characters of native sheep. M.Sc. Thesis, Fac. Agric. Cairo Univ. Egypt.

Mounib, M.S., Ahmed, I.A.And Hamada, .M.K.O. (1965) A study of the sexual behaviour of the female Rahmany sheep, Alex. J. Agric. Res. 4, 58.

Egypt. J. Anim. Prod. 20, No. 1 (1980) 
Ortavant, $\mathbb{R}$. (1956) The effect of the length of lighting on spermatogenesis in the ram. Compt. Rand. Soc. Biol. Paris, 150, 471 (A.B.A. 25, 224).

ProdHon, M., Calindez, F. and Reboul, G. (1976) Oestrous induction and paddock mating Aries Merion ewes:efiects of season, laction and the ram:ewe ratio In Ieres journees de la rechrache ovine et capine, 2-4 D3cember 1975.

Schinckel, P.G. 1954 The effect of presence of the ram on overain activity of the ewe; Aust Res,. 5, 465.

Snedecor, G.W. and Cochran, W.C. (1970) Statistical Methods th5 Ed. the Iowa State Press Ames, Iowa, U.S.A.

Vua Tonder, E.M. (1972)A review of some aspects concerning mating and reproduction in sheep. J.S. Atfic. Vet. Ass. 4, 329

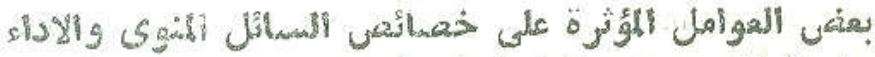

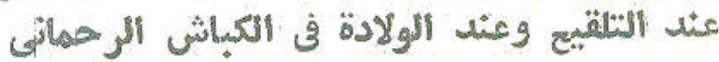

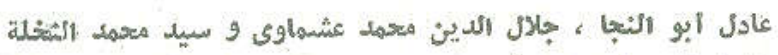

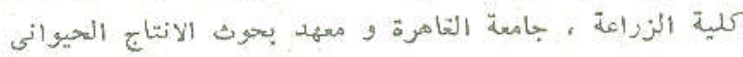

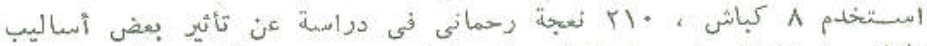

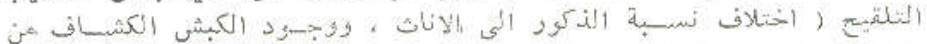

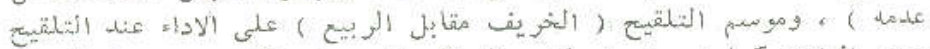

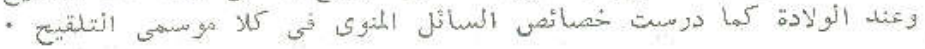

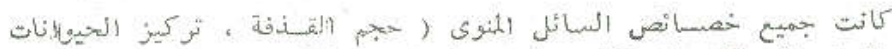

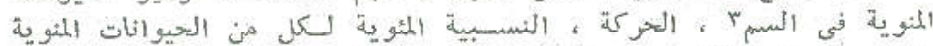

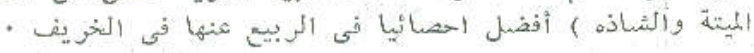

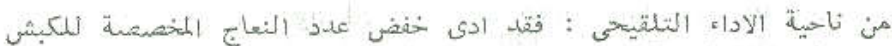

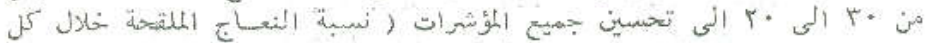

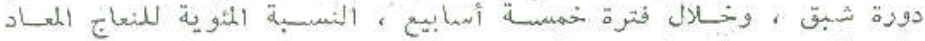

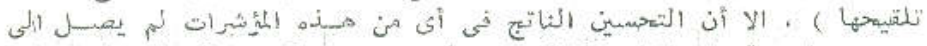

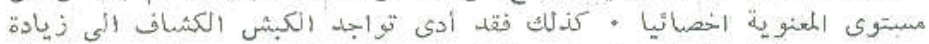

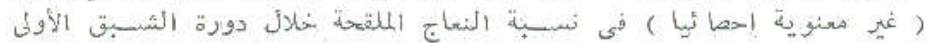

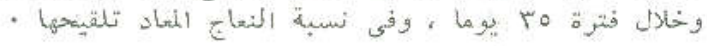

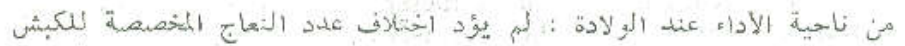

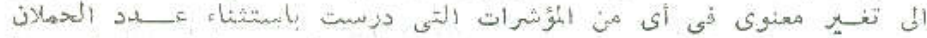

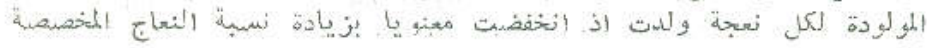
- للمكبش

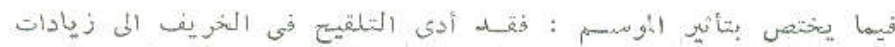

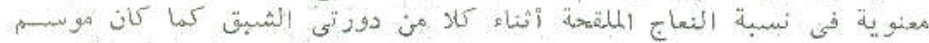

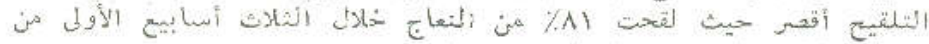

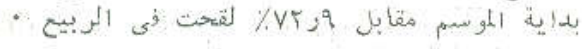

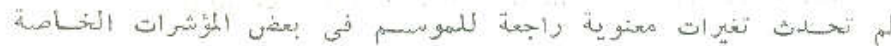

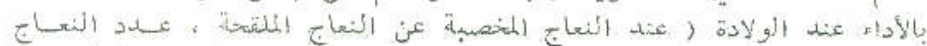

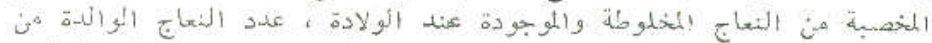

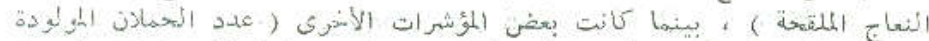

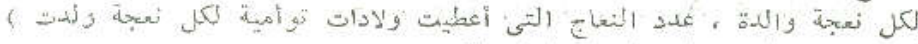

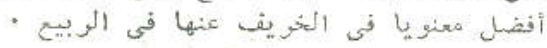

Egypt. J. Anim. Prod. 20, No. 1 (1980) 